\title{
PEMANFAATAN BEE POLLEN SEBAGAI SUMBER ZAT BESI DALAM PEMBUATAN CRACKERS
}

\author{
Fatimah Fitriani Mujahidah \\ ${ }^{\text {I}}$ Program Studi Gizi, Universitas Megarezky, Makassar \\ Email : fatimahfitrianim@gmail.com
}

\begin{abstract}
Nutritional problems relate directly to the quantity and quality of the food they consume.The research aimed to obtain crackers products that contain amino acids and iron with flour substitution bee pollen (bee pollen). This research was an experimental research with the labolatory analysis design. The research was carried out in three stages: the first stage was an introductory research with laboratory tests on bee pollen flour and organoleptic test, In the product initial research, proximate analysis was conducted, and amino acid content and iron suit of SNI. The research result of crackers formula C2 gives the good preference level. For the product initial research i.e. the proximate analysis, the selected formulas are $7.74 \%$ protein and $7.50 \%$ for the control formula, $22.81 \%$ fat and $21.95 \%$ for the control formula $63.61 \%$, carbohydrates and $64.67 \%$ for the control formula, water content $3.36 \%$ and $3.12 \%$ for the control formula, $2.52 \%$ ash content and $2.75 \%$. for the control formula. Fe content in bee pollen flour was 145.7862 ppm after being processed into crackers at $88.4402 \mathrm{ppm}$. This research reveals that the iron decreased after processed into crackers
\end{abstract}

Keywords : Bee Pollen, crackers, iron

\begin{abstract}
ABSTRAK
Masalah gizi balita berhubungan langsung dengan kuantitas dan kualitas makanan yang dikonsumsinya. Penelitian ini bertujuaan untuk mendapatkan produk crackers yang memiliki kandungan asam amino dan zat besi dengan substitusi tepung bee pollen (serbuk sari lebah). Jenis penelitian yang digunakan adalah quai eksperimen dengan desain analisis labolatorium. Penelitian dilakukan 3 tahap, tahap pertama melakukan penelitian pendahuluan dengan uji laboratorium terhadap tepung dan uji organoleptik, Penelitian awal produk dilakukan analisis proksimat dan penelitian analisis kandungan asam amino dan zat besi sesuai dari SNI. Hasil penelitian formula crackers II memberikan tingkat kesukaan yang baik. Untuk penelitian awal produk yakni analisis proksimat, formula terpilih 7,74\% untuk protein dan $7,50 \%$ formula kontrol, lemak $22,81 \%$ formula terpilih dan $21,95 \%$ formula kontrol, Karbohidrat $63,61 \%$ formula terpilih dan $64,67 \%$ formula control, Kadar air 3,36\% formula terpilih dan $3,12 \%$ formula kontrol, kadar abu 2,52\% formula terpilih, 2,75\% formula kontrol. Kadar Fe pada tepung bee pollen sebesar $145.7862 \mathrm{ppm}$ setelah diolah menjadi crackers sebesar $88.4402 \mathrm{ppm}$. Adapun kesimpulan dalam penelitian ini yaitu kandungan zat besi mengalami penurunan setelah diolah menjadi crackers
\end{abstract}

Kata Kunci : Bee Pollen, Crackers, Zat Besi 


\section{Vol. 16 No.2 Mei - Agustus 2021}

\section{PENDAHULUAN}

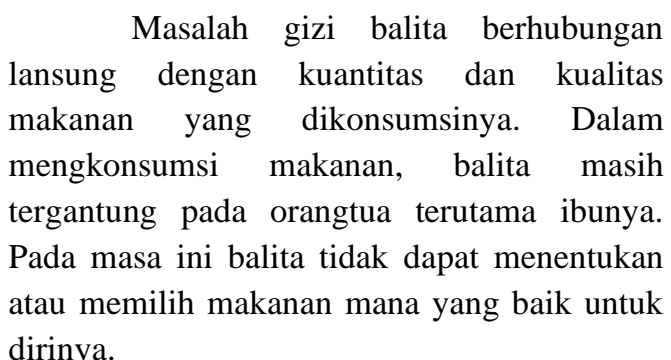

Defisiensi besi merupakan masalah di negara berkembang. Permasalahan gizi di Indonesia salah satunya adalah anemia, anemia adalah kondisi medis dimana jumlah sel darah merah atau haemoglobin kurang dari normal. Kadar Haemoglobin normal umumnya berbeda pada orang tua dan anak-anak, untuk orang tua laki-laki angka normal $\mathrm{Hb}$ adalah 13,5 gram $\%$, pada orang dewasa perempuan angka normal $\mathrm{Hb}$ adalah 12 gram \% sedangkan pada anak-anak adalah 11 gram \% (Proverawati, 2011). Prevalensi anemia 29, 1\% (Ghassemi \& Keikhaei, 2014). Anemia terjadi pada $80 \%$ anak usia 6-23 bulan (Prietopatron et al., 2017). Anemia dominan pada bayi laki-laki, sedangkan puncak defisiensi besi pada bayi pada umur 9-12 bulan. Apabila anemia terjadi pada orang dewasa akan mudah diketahui, akan tetapi apabila anemia terjadi pada bayi atau balita, hal ini sangat tidak cepat terdeteksi, karena bayi/balita belum bisa mengungkapkan apabila mengalami tandatanda anemia.

Anemia gizi dapat disebabkan oleh defisiensi zat besi, asam folat, vitamin B12 dan vitamin A.

Kurangnya besi berpengaruh dalam pembentukan hemoglobin, sehingga kosentrasinya dalam sel darah merah berkurang. Hal ini akan mengakibatkan tidak adekuatnya pengangkutan oksigen keseluruh jaringan tubuh (Nopiana, 2013). Menurut World Health Organization pada tahun 2013, kekurangan zat besi sebagai salah satu dari sepuluh masalah kesehatan yang paling serius.

Berdasarkan nilai rujukan Riskesdes tahun 2013 "proporsi anemia menurut umur, jenis kelamin, dan tempat tinggal, jumlah penderita anemia umur 5-14 tahun adalah $26,4 \%$, jumlah penderita jenis kelamin lakilaki adalah $18,4 \%$, jenis kelamin perempuan $23,9 \%$, jumlah penderita yang tinggal di perkotaan $20,6 \%$, pedesaan $22,8 \%$, sedangkan jumlah penderita anemia di Indonesia mencapai 21,7\%" (Kemenkes

RI, 2013). Terjadinya kekurangan zat besi pada tubuh dapat memengaruhi kemampuan

hemoglobin dalam membawa oksigen ke seluruh tubuh. Seluruh reaksi kimia di dalam tubuh memerlukan oksigen sebagai bahan bakar.

Crackers adalah jenis biskuit yang terbuat dari adonan keras melalui proses fermentasi atau pemeraman, berbentuk pipih yang mengarah kepada rasa asin dan relatif renyah, serta bila dipatahkan penampang potongannya berlapis-lapis. Produk crackers saat ini mengalami perkembangan dengan variasi campuran antara tepung terigu sebagai bahan baku utama dengan bahan - bahan makanan lainnya yang bertujuan meningkatkan kandungan gizi crackers tersebut (Dewan ketahanan pangan, 2009). Berbagai studi intervensi yang dilakukan berkaitan dengan penggunaan crackers sebagai media fortifikasi diantaranya yaitu Penelitian yang dilakukan oleh (Jain, 2013) bahwa pemberian biskuit yang diperkaya zat besi selama empat bulan intervensi pada anak perempuan menunjukkan hasil yang signifikan terhadap $\mathrm{Hb}$ dan hematologis. Penelitian serupa dilakukan oleh (Bahar, dkk 2013) menunjukkan adanya peningkatan $\mathrm{Hb}$ pada anak - anak sekolah dengan pemberian bee polen.

Studi-studi tersebut menunjukkan bahwa biskuit crackers dapat dijadikan sebagai media yang cukup berhasil dalam program fortifikasi makanan tambahan untuk anak sekolah, dimana biskuit biasanya lebih dipilih sebagai makanan camilan (snack) dibandingkan sebagai makanan utama. 


\section{METODE}

\begin{abstract}
Penelitian ini bertempat di Laboratorium Jurusan Gizi Kesehatan Masyarakat untuk uji organoleptik pada panelis semi terlatih. Untuk Uji Proksimat, dan zat besi dilaksanakan di Laboratorium Mikrobiologi Universitas Hasanuddin Makassar. Penelitian ini menggunakan metode quasi eksperimen dengan analisa laboratorium,satu perlakuan empat taraf dan dua kali pengulangan, dimana pelaksanaannya dibagi dalam dua tahap yaitu penelitian pendahuluan dan penelitian utama. Penelitian pendahuluan bertujuan untuk mengetahui kandungan zat besi yang terkandung dalam tepung bee pollen, selain itu untuk memperoleh perbandingan resep terbaik dari bahan-bahan yang akan digunakan pada penelitian awal produk. Pada penelitian awal produk dilakukan uji organoleptik menggunakan uji hedonic pada panelis, kemudian ditentukan satu produk dan produk sebagai control yang dinyatakan sebagai produk yang terbaik kemudian dilakukan analisis proksimat dan dilakukan uji asam amino dan zat besi terhadap produk terpilih.
\end{abstract}

\section{Jenis-jenis dan Cara Pengumpulan Data}

Data yang akan dikumpulkan adalah data pimer yang terdiri dari : Data kesukaan atau Uji Organoleptik terhadap kriteria warna, rasa, aroma serta tekstur.Data analisis proksimat, dan zat besi. Pengumpulan data berupa data uji kimia atau biasa disebut dengan analisis proksimat yaitu menganalisis kandungan protein,lemak,kadar abu,kadar karbohidrat,kadar serat kasar dan kadar air

Data daya terima diperoleh dengan menggunakan formulir penilaian yang diberikan kepada panelis dengan prosedur dan kriteria penilaian panelis yakni kepada panelis diberi penjelasan tentang tujuan dan cara pengisian formulir, Sampel yang akan dinilai diletakkan dikemas dengan kode tertentu, Formulir penilaian terlampir bersampel yang akan dinilai dan diletakkan di meja panelis, Penilaian organoleptik dilakukan dengan warna, rasa, aroma dan tekstur, Untuk menetralkan rasa dan aroma masing-masing produk maka panelis diberi air putih. Sedang Untuk kriteria panelis yakni Panelis peka terhadap atribut yang dinilai, Sehat (tidak sedang mengidap suatu penyakit yang dapat mengganggu penilaian) seperti Pilek, dll. Serat panelis tidak dalam keadaan lapar..

\section{HASIL DAN PEMBAHASAN}

\section{Penelitian Pendahuluan}

Pada penelitian pendahuluan difokuskan terhadap pembuatan tepung. Bee Pollen yang merupakan bahan baku subtitusi pada pembuatan crackers ini diperoleh di Desa Bengo - Bengo yaitu dari hutan pendidikan Unhas yang dikelola oleh salah seorang dosen Unhas yang bernama Prof. Mappatoba Sila. Cara pengambilan bee pollen ini yaitu pertama - tama sarang lebah yang terdapat dalam koloni dikeluarkan kemudian bee pollen yang terdapat dalam sarang lebah dipisahkan dengan propolis dan larva lebah menggunakan pinset. Setelah bee pollen ini terpisah, selanjutnya pembuatan tepung. Pembuatan tepung dilakukan dengan cara bee pollen disimpan di dalam wadah stainless steel yang ditutupi kain rang kemudian dikeringkan di bawah matahari selama 1 hari. Setelah itu, bee pollen tersebut di blender lalu dilakukan pengayakan menggunakan ayakan 60 mesh untuk dijadikan tepung dengan tekstur yang lebih halus. Pada penelitian pendahuluan juga dilakukan uji proksimat, dan zat besi. Untuk uji proksimat pada tepung bee pollen, hasil yang didapatkan yakni kadar air (4,32\%), untuk protein kasar $(11,60 \%)$, untuk lemak kasar (19,65\%), untuk serat kasar $(6,12 \%)$, untuk karbohidrat $(64,20 \%)$, dan kadar abu (2,12\%).

\section{Penelitian Utama}

Pada penelitian utama adalah proses pembuatan crackers dengan penambahan tepung bee pollen. Tepung bee pollen yang ditambahkan pada crackers menggunakan formula bee pollen 25\%,75\%,100\% dan dilakukan oleh 20 orang panelis. 


\section{Vol. 16 No.2 Mei - Agustus 2021}

A. Hasil analisis subtitusi tepung bee pollen pada crackers (crackers) terhadap tingkat kesukaan panelis

Berdasarkan tabel 1, menunjukkan orang (80\%) tidak jauh berbeda dengan jumlah jumlah panelis anak perempuan sebanyak 16 panelis laki-laki sebanyak $4(20 \%)$.

Tabel 1 Distribusi panelis menurut kelas dan jenis kelamin

\begin{tabular}{ccc}
\hline Karakteristik & N & \% \\
\hline Jenis Kelamin & & \\
- Laki-laki & 4 & 20 \\
- Perempuan & 16 & 80 \\
\hline Total & $\mathbf{2 0}$ & $\mathbf{1 0 0}$
\end{tabular}

Uji kesukaan panelis terhadap kelima tipe crackers dianalisis menggunakan uji anova satu arah Kruskal-Wallis. Berdasarkan hasil analisis statistik terhadap daya terima panelis pada kelima tipe crackers dengan tingkat subtitusi tepung bee pollen yang berbeda, yaitu: subtitusi $0 \%, 25 \%, 50 \%$, dan $75 \%$ dan $100 \%$ melalui dua kali ulangan tidak berpengaruh terhadap kesukaan panelis $(p=0,917)$. Hal ini berarti bahwa penerimaan crackers oleh panelis sama, baik yang disubtitusi tepung bee pollen maupun yang tidak disubtitusi atau dalam hal ini baik yang disubtitusi atau tidak disubtitusi dapat diterima oleh panelis.

Tabel 2 Uji kesukaan panelis

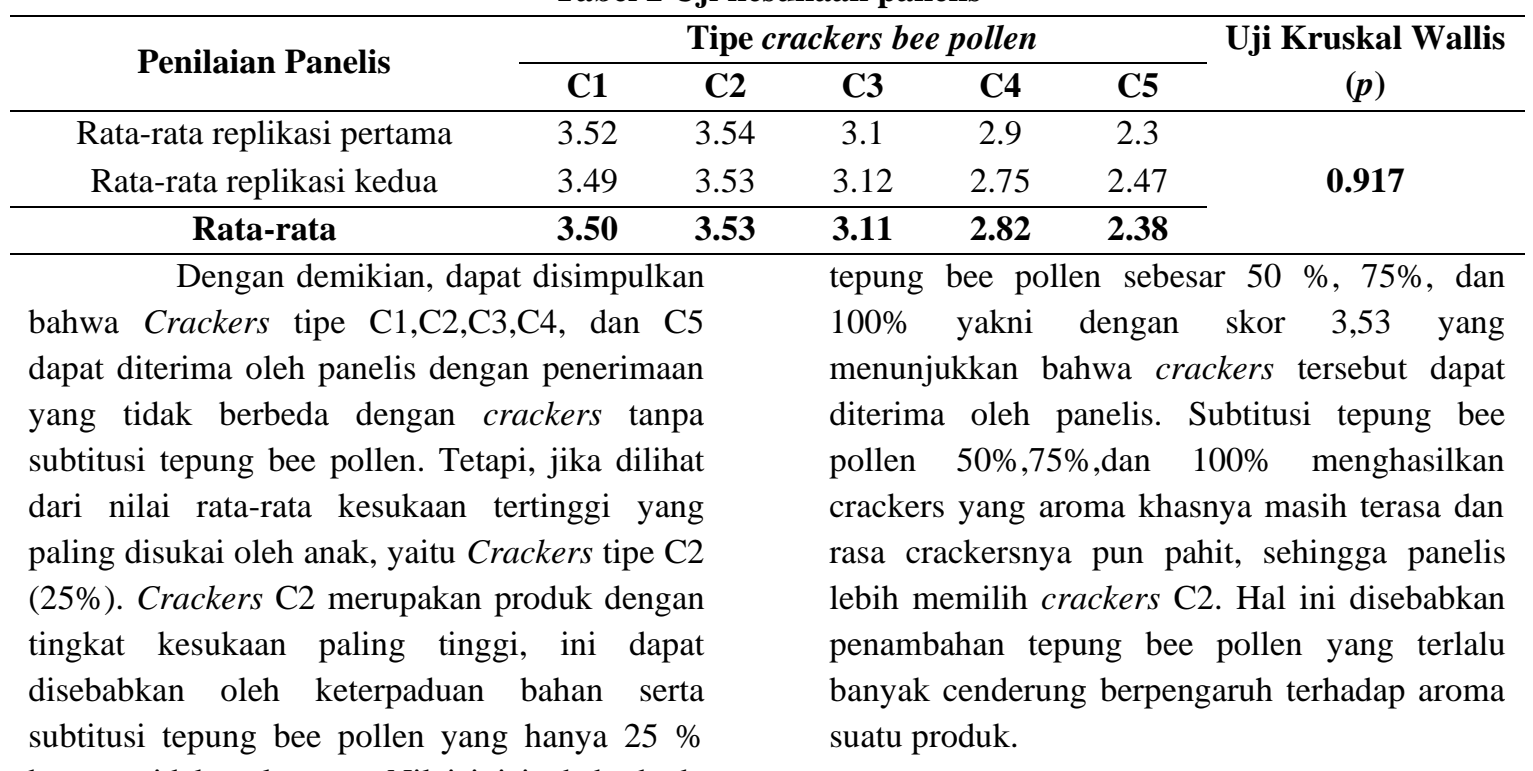
baunya tidak terlampau. Nilai ini jauh berbeda dengan crackers $\mathrm{C} 3, \mathrm{C} 4$, dan C5 yakni subtitusi

\section{B. Hasil Analisis Subtitusi Tepung Bee Pollen Terhadap Mutu Kesukaan Crackers}

Pengujian organoleptik dilakukan dengan uji mutu kesukaan atau uji mutu organoleptik ini meliputi uji kesukaan terhadap hedonik menggunakan 20 orang panelis. Uji aroma, rasa, tekstur, dan warna.

Tabel 3 Rata-Rata kesukaan panelis semi terlatih pada formula crackers

\begin{tabular}{cccccc}
\hline Formula crackers & Aroma & Warna & Rasa & Tekstur & $\begin{array}{c}\text { Uji Kruskall-Wallis } \\
(\mathbf{p = 0 , 0 5})\end{array}$ \\
\hline C1 & 3.60 & 3.80 & 4.00 & 3.20 & $\mathbf{0 . 0 0 0}$ \\
C2 & 4.10 & 3.20 & 3.60 & 2.95 &
\end{tabular}




\begin{tabular}{rllll} 
C3 & 3.15 & 2.25 & 2.95 & 2.70 \\
C4 & 2.35 & 1.80 & 2.65 & 2.60 \\
C5 & 1.95 & 1.40 & 1.95 & 1.90 \\
\hline
\end{tabular}

1) Aroma
Skor rata-rata mutu kesukaan untuk aroma crackers disubtitusi dengan tepung bee pollen berkisar antara 1,95 - 4,10. Tingkat kesukaan panelis terhadap aroma crackers berkisar antara sangat tidak suka sampai sangat suka. Crackers tipe C2 dengan subtitusi tepung bee pollen $25 \%$ memiliki nilai rata-rata aroma lebih tinggi dari crackers tipe lainnya yaitu 4,10 (Tabel 3). Nilai ini menunjukkan bahwa penerimaan panelis terhadap crckers tipe C2 adalah agak suka. Berdasarkan hasil analisis varians satu arah Kruskal-Wallis diperoleh bahwa tingkatan subtitusi tepung bee pollen pada formula crackers berpengaruh secara nyata terhadap aroma crackers $p=0,000$. Hal ini disebabkan oleh penambahan bee pollen yang sesuai sehingga memberikan aroma yang lebih menarik, harum, dan mudah diterima oleh masyarakat luas.

Rendahnya persentase pada produk crackers dengan subtitusi 50\%, 75\%, dan $100 \%$ disebabkan karena aroma pada penambahan bee pollen terlalu bau dan juga rasa pahit, sehingga hal ini mempengaruhi aroma panelis. Aroma yang disebarkan oleh makanan merupakan daya tarik yang sangat kuat dan mampu merangsang indera penciuman sehingga membangkitkan selera. Timbulnya aroma makanan disebabkan oleh terbentuknya senyawa yang mudah menguap itu dapat sebagai akibat atau reaksi karena pekerjaan enzim atau dapat juga terbentuk tanpa bantuan reaksi enzim.

\section{2) Rasa}

Tabel 3 menunjukkan hasil analisis varians satu arah Kruskal-Wallis diperoleh bahwa tingkatan subtitusi tepung bee pollen pada formula crackers berpengaruh secara nyata terhadap rasa crackers $p=0,000$. Hal ini menunjukkan bahwa perlakuan subtitusi tepung bee pollen dengan tingkat yang berbeda-beda mempengaruhi rasa daripada crackers tersebut. Hal ini ditunjukkan dengan nilai rata-rata penilaian panelis yang berbeda untuk setiap tipe formula crackers. Formula crackers yang disubtitusi tepung bee pollen yang memiliki skor tertinggi dibanding formula subtitusi tepung bee pollen yang lain adalah crackers B dengan subtitusi $25 \%$ dengan rata-rata skor 3,60 (tabel 3). Nilai ini menunjukkan penerimaan panelis terhadap crackers B dengan respon cukup enak. Nilai ini sedikit lebih rendah dibanding dengan crackers A, dimana panelis menilai crackers A memiliki rasa yang enak yang ditandai dengan nilai rata - rata yaitu 4,00. 3) Warna

Nilai rata-rata warna formula crackers subtitusi tepung bee pollen dengan tingkatan subtitusi yang berbeda berkisar antara 1,40-3,80 (Tabel 3). Hasil analisis varians diperoleh tingkatan subtitusi tepung bee pollen pada formula crackers memberikan pengaruh terhadap warna formula crackers. Dari tabel tersebut dapat dilihat bahwa semakin tinggi konsentrasi bee pollen terhadap crackers, maka panelis kurang suka terhadap warna dari crackers tersebut. Crackers dengan subtitusi tepung bee pollen sebesar $25 \%$ menunjukan nilai rata - rata 3,20 dimana menunjukkan bahwa crackers B menarik. Nilai ini sedikit lebih rendah dibanding dengan crackers A yaitu 3,80 .

Hasil uji menggunakan KruskalWallis menunjukkan bahwa perlakuan konsentrasi penambahan tepung bee pollen memberikan pengaruh terhadap warna cracker $(\mathrm{P}=0,000)$. Faktor utama yang menentukan warna crackers adalah proses pemanggangan. Hal tersebut sesuai dengan penjelasan (Faridi, 1994) bahwa tahap terakhir dalam proses pemanggangan merupakan proses yang menentukan pembentukan warna dari crackers. Suhu pemanggangan yang tinggi akan menghasilkan warna coklat yang lebih gelap.

\section{4) Tekstur}

Penilaian terhadap tekstur merupakan penilaian utama pada produk crackers. Tekstur cracker yang diharapkan adalah crackers dengan tekstur renyah. Pada crackers dengan subtitusi tepung bee pollen tingkat kesukaan panelis terhadap tekstur berkisar antara 1,90 - 3,20 yang menunjukkan bahwa panelis menilai tekstur crackers berkisar antara sangat tidak renyah hingga agak renya.hasil analisis 


\section{Vol. 16 No.2 Mei - Agustus 2021}

menunjukkan bahwa subtitusi tepung bee polen terhadap tekstur crackers berpengaruh nyata. Nilai rata - rata penilaian panelis menunjukkan bahwa crackers A memiliki skor tertinggi dibanding dengan crackers lainnya, namun untuk crackers subtitusi tepung bee pollen, skor tertinggi yaitu formula crackers $\mathrm{B}$ dengan nilai rata - rata 2,90.

Tekstur biskuit yang baik banyak dipengaruhi oleh proses pemanasan serta bahanbahan pembentuk adonan. Selain itu, proses pembuatan juga mempengaruhi tekstur biskuit yang dihasilkan. Selain itu, crackers menghasilkan tekstur yang renyah disebabkan karena adanya fermentasi, serta metode pemotongan adonan seperti datar atau timbul juga mempengaruhi tekstur yang dihasilkan.
Adanya penambahan tepung terigu (pati) dalam pembuatan biskuit, selama pemanasan akan mengalami gelatinisasi yang menyebabkan biskuit memiliki tektur yang sangat lembut (Manley, 2000). Gelatinisasi adalah pembengkakan granula pati dengan adanya air (Winarno, 2008). Tekstur crackers yang renyah dan berlapis disebabkan adanya penambahan soda kue, hal ini didukung oleh penjelasan (Stauffer, 1990) bahwa reaksi pembentukan gas $\mathrm{CO} 2$ dari sodium bikarbonat biasanya dapat terjadi jika terdapat suhu yang tinggi $\left(>120^{\circ} \mathrm{C}\right)$, sehingga penggunaan sodium bikarboanat dalam pembuatan cookie dan crackers terbatas pada suhu internal yang mendekati kisaran suhu tersebut.

\section{Hasil Analisis Proksimat, dan zat besi Subtitusi Tepung Bee Pollen Terpilih}

\section{1) Kadar air}

Kadar air yang diperoleh dengan cara analisis laboratorium dari crackers substitusi tepung bee pollen yang terpilih yaitu crackers tipe C2 dengan subtitusi $25 \%$ tepung bee pollen dengan crackers tipe $\mathrm{C} 1$ yaitu tanpa subtitusi. secara jelas dapat dilihat pada tabel 4 .

Tabel 4 Hasil analisis kadar air (\%) kedua tipe crackers

\begin{tabular}{ccc}
\hline \multirow{2}{*}{ Ulangan } & \multicolumn{2}{c}{ Tipe Crackers } \\
\cline { 2 - 3 } & $\mathrm{C} 1$ & $\mathrm{C} 2$ \\
\hline 1 & 3.09 & 3.32 \\
2 & 3.15 & 3.41 \\
\hline Rata-rata & $\mathbf{3 . 1 2}$ & $\mathbf{3 . 3 6}$ \\
\hline
\end{tabular}

Tabel 4 menunjukkan ada perbedaan antara crackers tanpa subtitusi dengan crackers subtitusi $25 \%$ terhadap kadar air. Terlihat dari

\section{2) Kadar Abu}

Kadar Abu yang diperoleh dengan cara analisis laboratorium dari crackers baik yang disubtitusi tepung bee pollen maupun tidak rata-rata $\mathrm{C} 1$ yaitu 3,12 sedangkan untuk formula crackers $\mathrm{C} 2$ rata - rata kadar air yaitu 3,36.

disubtitusi secara jelas dapat dilihat pada tabel 5 .

Tabel 5 Kadar abu (\%) kedua tipe crackers

\begin{tabular}{ccc}
\hline \multirow{2}{*}{ Ulangan } & \multicolumn{2}{c}{ Tipe Crackers } \\
\cline { 2 - 3 } & C1 & C2 \\
\hline 1 & 2.81 & 2.57 \\
2 & 2.69 & 2.48 \\
\hline Rata-rata & $\mathbf{2 . 7 5}$ & $\mathbf{2 . 5 2}$ \\
\hline
\end{tabular}


Tabel 5 memperlihatkan bahwa subtitusi tepung bee pollen berpengaruh terhadap kadar abu. Terlihat dari rata-rata tipe 3) Kadar Protein

Kadar protein yang diperoleh dengan cara analisis laboratorium dari crackers baik yang disubtitusi tepung bee pollen maupun tidak
C1 yaitu 2,75 lebih tinggi dibandingkan dengan rata-rata tipe $\mathrm{C} 2$ yaitu 2,52 .

disubtitusi secara jelas dapat dilihat pada tabel 6

Tabel 6 Hasil analisis kadar protein (\%) kedua tipe crackers

\begin{tabular}{ccc}
\hline \multirow{2}{*}{ Ulangan } & \multicolumn{2}{c}{ Tipe Crackers } \\
\cline { 2 - 3 } & $\mathbf{C 1}$ & $\mathbf{C 2}$ \\
\hline 1 & 7.54 & 7.68 \\
2 & 7.46 & 7.80 \\
\hline Rata-rata & $\mathbf{7 . 5 0}$ & $\mathbf{7 . 7 4}$ \\
\hline
\end{tabular}

Tabel 6 tersebut, menunjukkan ratarata kadar protein pada kedua tipe crackers berkisar antara 7,50\% - 7,74\%. Tabel tersebut juga menunjukkan crackers tanpa subtitusi

\section{4) Kadar lemak}

Kadar lemak yang diperoleh dengan cara analisis laboratorium dari crackers baik tepung bee pollen lebih rendah proteinnya dibandingkan dengan crackers subtitusi tepung bee pollen yang terpilih

yang disubtitusi tepung bee pollen maupun tidak disubtitusi secara jelas dapat dilihat pada tabel 7

Tabel 7 Hasil analisis kadar lemak (\%) kedua tipe crackers.

\begin{tabular}{ccc}
\hline \multirow{2}{*}{ Ulangan } & \multicolumn{2}{c}{ Tipe Crackers } \\
\cline { 2 - 3 } & $\mathbf{C 1}$ & $\mathbf{C 2}$ \\
\hline 1 & 21.92 & 22.86 \\
2 & 21.99 & 22.76 \\
\hline Rata-rata & $\mathbf{2 1 . 9 5}$ & $\mathbf{2 2 . 8 1}$ \\
\hline
\end{tabular}

Tabel 7 menunjukkan rata-rata kadar lemak pada kedua tipe crackers berkisar antara $21,95 \%$ - 22,81\%. Tabel tersebut juga menunjukkan crackers tanpa subtitusi tepung

\section{5) Kadar Karbohidrat}

Kadar karbohidrat yang diperoleh dengan cara analisis laboratorium dari crackers baik yang disubtitusi tepung bee pollen maupun bee pollen lebih rendah kadar lemaknya dibandingkan dengan crackers subtitusi tepung bee pollen yang terpilih.

Tabel 8 Hasil analisis kadar karbohidrat (\%) kedua tipe crackers

\begin{tabular}{ccc}
\hline \multirow{2}{*}{ Ulangan } & \multicolumn{2}{c}{ Tipe Crackers } \\
\cline { 2 - 3 } & C1 & C2 \\
\hline 1 & 64.64 & 63.67 \\
2 & 64.71 & 63.55 \\
\hline Rata-rata & $\mathbf{6 4 . 6 7}$ & $\mathbf{6 3 . 6 1}$
\end{tabular}

Tabel 8 memperlihatkan bahwa nilai rata-rata crackers tipe C1 yaitu $(64,67 \%)$ lebih

\section{6) Kadar Serat}

Kadar serat yang diperoleh dengan cara analisis laboratorium dari crackers baik yang disubtitusi tepung bee pollen maupun tidak

tidak disubtitusi secara jelas dapat dilihat pada tabel 8.

Tabel 9 Hasil analisis kadar serat (\%) kedua tipe crackers

\begin{tabular}{ccc}
\hline \multirow{2}{*}{ Ulangan } & \multicolumn{2}{c}{ Tipe Crackers } \\
\cline { 2 - 3 } & $\mathrm{C} 1$ & $\mathrm{C2}$ \\
\hline
\end{tabular}




\section{Vol. 16 No.2 Mei - Agustus 2021}

\begin{tabular}{ccc}
\hline 1 & 3.80 & 5.43 \\
2 & 3.58 & 4.92 \\
\hline Rata-rata & $\mathbf{3 . 6 9}$ & $\mathbf{5 . 1 8}$
\end{tabular}

Tabel 9 memperlihatkan bahwa nilai rata-rata tipe $\mathrm{C} 1 \quad(3,69)$ lebih rendah dibandingkan dengan rata-rata tipe $\mathrm{C} 2(5,18)$. 7) Kadar Zat Besi

Kadar Fe cracers yang diberi perlakuan substitusi tepung bee pollen dengan konsentrasi $25 \%$ menunjukkan hasil uji yaitu 88.4402 ppm. Kadar Fe tepung bee pollen adalah $145.7862 \mathrm{ppm}$. Kadar Fe tepung bee pollen dalam proses pencampuran dan pengolahan mengalami penurunan. Proses pemanasan pada suhu tinggi merupakan faktor utama yang dapat menurunkan kadar Fe. Proses

\section{KESIMPULAN}

Adapun kesimpulan dari penelitian ini yaitu daya terima panelis terhadap produk crackers dengan penambahan bee pollen pada konsentrasi formula yang berbeda terdapat pada Formula crackers C2. Penerimaan mutu crackers subtitusi tepung bee pollen memberikan pengaruh yang bermakna terhadap warna, tekstur, aroma, dan rasa. Dari hasil skor rata-rata kesukaan yang paling dapat diterima oleh panelis semi terlatih atau mahasiswa adalah crackers tipe $\mathrm{C} 2$. Kandungan zat besi pada tepung bee pollen mengalami penurunan setelah diolah menjadi crackers

\section{DAFTAR PUSTAKA}

Bahar, dkk. 2013. Pengaruh pemberian honey bee pollen terhadap status gizi dan prestasi anak sekolah dasar yang menderita anemia di kota makassar.Universitas Hasanuddin. Makassar

Burke, et al. 2014. Identification, Prevention and Treatment of Iron Deficiency during the First 1000 Days. Journal Nutrients, 6, 4093-4114.

Dewan Ketahanan Pangan. 2009. Peta ketahanan dan kerentangan pangan Indonesia. Jakarta
Pada tabel tersebut terlihat crackers dengan subtitusi tepung bee pollen lebih tinggi kadar seratnya dibandingkan tanpa subtitusi.

pemanggangan crackers dilakukan pada suhu $120^{\circ} \mathrm{C}$ menyebabkan terjadinya penurunan kadar Fe. Hasil tersebut sesuai dengan hasil penelitian (Burke, et al. 2014) bahwa proses pemanasan menghasilkan penurunan kadar $\mathrm{Fe}$ dalam bentuk heme dalam jumlah besar terutama pada berbagai daging. Peningkatan pelepasan Fe dari heme terjadi ketika suhu ditingkatkan mulai dari $85^{\circ} \mathrm{C}$ sampai $100^{\circ} \mathrm{C}$.

Dewan Standarisasi Nasional Indonesia. 1992. SNI: 01-2973-1992. Mutu dan cara uji biskuit. Jakarta.

Faridi,, H. 1994 Technology of cookie and cracker production. Chapman and Hall. New York

Ghassemi, A., \& Keikhaei, B. 2014. Effects of Nutritional Variables in Children with Iron Deficiency Anemia. International Journal of Pediatric, 2(7), 183-187.

Jain, M. 2013. Combinating iron deficiency anemia through food to food fortification : recipe developmen, iron bioavailability and effect of supplementation. IJFANS : $2320-7876$

Kemenkes RI. 2013. Riset Kesehatan Dasar. http://www.depkes.go.id

Manley, D. 2000. Technology of biscuit, crackers and cookies. Third Edition. Woodhead publishig limited. England

Nopiana. 2013. Pengaruh pemberian ekstrak etanol $70 \%$ daun kelor (Moringa oleifera Lamk.) terhadap tekanan darah tikus putih betina anemia. Depok (Indonesia): Universitas Indonesia

World Health Organization. 2013. Micronutrient Deficiency. USA: World Health Organization

Prieto-patron, et al. 2017. The association between complementary foods and hemoglobin concentrations in indian infants. Journal of Human Nutrition \& 
Food Science, 5, 1-11.

Proverawati, A., \& Wati, E. K. 2011. Ilmu gizi untuk keperawatan dan gizi kesehatan.

Yogyakarta: Nuha Medika.

Winarno, F. G. 2008. Kimia pangan dan

gizi. PT Gramedia Pustaka

Umum. Jakarta 